\title{
Observations on the Digestibility and Nutritive Value of the Nitrogenous Constituents of Wheat Bran
}

\author{
By H. CHICK, M. E. M. CUTTING, C. J. MARTIN ANd E. B. SLACK \\ Lister Institute of Preventive Medicine, London, S.W. I
}

(Received 7 Fune 1947)

Commercial bran is a product of the roller milling of wheat. The first crushing effects a rough division of the endosperm from the outer coats of the kernel, which are separated by sieving together with some $10-15 \%$ of the adherent endosperm. It varies in composition according to the type of wheat and the technical details of milling. Pure or clean bran is generally regarded as consisting of the pericarp, seed coats and aleurone layer, as the last, although morphologically the outermost layer of the endosperm, remains firmly attached to the seed coats and resists separation by mechanical means. A good description, with drawings, of the microscopical appearances of the different tissues composing wheat bran is given by Winton \& Winton (1932).

Table r. Estimated composition of $100 \mathrm{~g}$. dry wheat of nitrogen content $2 \cdot 2 \%$ (Osborne \& Mendel, I9r9; based on Girard, 1884)

\begin{tabular}{|c|c|c|c|c|c|}
\hline \multicolumn{4}{|c|}{ (Approximate values.) } & \multicolumn{2}{|c|}{ Total nitrogen } \\
\hline Fraction & $\begin{array}{c}\text { Percentage } \\
\text { by weight } \\
\text { of grain }\end{array}$ & $\begin{array}{c}\text { Nitrogen } \\
\text { content } \\
(\%)\end{array}$ & $\begin{array}{c}\text { Protein } \\
\text { content* } \\
(\%)\end{array}$ & (g.) & $\begin{array}{c}\text { As } \\
\text { percentage } \\
\text { of total } \\
\text { nitrogen } \\
\text { in grain }\end{array}$ \\
\hline Clean bran (including aleurone) & I5 & $3 \cdot 3$ & $18 \cdot 7$ & 0.49 & $22 \cdot 3$ \\
\hline Aleurone layer & 9 & 4.0 & $25^{\cdot 8}$ & 0.35 & $15^{\circ} 9$ \\
\hline Germ & $I \cdot 5$ & $6 \cdot 7$ & $36 \cdot 7$ & 0.10 & 4.4 \\
\hline Endosperm & $83 \cdot 5$ & $1 \cdot 9$ & II I I & $I \cdot 6 I$ & $73 \cdot 2$ \\
\hline
\end{tabular}

Osborne \& Mendel (I9r9) estimated that, of the weight of the whole grain, clean bran constituted about $15 \%$, of which more than half corresponded to the aleurone, the germ I.5\% and the endosperm $83.5 \%$ (see Table $\mathrm{r}$ ). These workers also made a complete analysis of the sample of commercial bran employed in their nutrition experiments. From the starch content they decided that it contained $17 \%$ of adherent endosperm, and they estimated the percentage composition of the pure bran, on a dryweight basis, to be approximately as follows: soluble carbohydrate $7 \cdot 0$, pentosans, etc. $33 \cdot 0$, protein $(\mathrm{N} \times 6 \cdot 25)$ I $8 \cdot 0$, fibre $1 \mathrm{I} \cdot 2$, fat 8.3 , ash $8 \cdot 6 ; 14 \%$ of the total weight remained unaccounted for.

A comprehensive study of the component parts of bran was made by Girard (1884). The outer coverings of the grain (enveloppe), when carefully separated by.hand so 
that no starchy endosperm adhered, were found by him to constitute about $14.4 \%$ of the total weight of the grain and to contain $2.9 \%$ nitrogen, or about $17 \%$ protein. By a combination of experiments, in some of which the enveloppe was subjected to various chemical treatments and microscopical examination made of the residue, and in others where the different layers were separated by hand and analysed, the figures given in Table 2 were obtained. From these figures, which represent mean values derived from several samples of wheat including both European and Australian varieties, it will be seen that the aleurone layer and the germ are the most proteinaceous components of the wheat kernel. The figures in Table I, which are also based on

Table 2. Composition of clean* wheat bran (enveloppe) and its component parts (Computed from figures of Girard, 1884)

\begin{tabular}{|c|c|c|c|c|c|c|}
\hline \multirow[b]{2}{*}{ Fraction } & \multicolumn{2}{|c|}{ Amount } & \multirow[b]{2}{*}{$\begin{array}{c}\text { Water } \\
\text { content } \\
(\%)\end{array}$} & \multicolumn{3}{|c|}{ Nitrogen content } \\
\hline & $\begin{array}{l}\text { In } 100 \mathrm{~g} . \\
\text { wheatf } \\
\text { (g.) }\end{array}$ & $\begin{array}{c}\text { As percentage } \\
\text { by weight } \\
\text { of bran }\end{array}$ & & $\begin{array}{c}\text { On fresh } \\
\text { weight } \\
(\%)\end{array}$ & $\begin{array}{c}\text { On dry } \\
\text { weight } \\
(\%)\end{array}$ & $\begin{array}{l}\text { Total in } \\
\text { fraction } \\
\text { (g.) }\end{array}$ \\
\hline Pericarp & $4 \cdot 4$ & $31 \cdot 0$ & II $\cdot 3$ & 1.23 & $I \cdot 38$ & 0.054 \\
\hline Testa & $1 \cdot 2$ & $7 \cdot 7$ & $11 \cdot 7$ & $2 \cdot 60$ & 2.95 & 0.031 \\
\hline $\begin{array}{l}\text { Aleurone layer and } \\
\text { nucellus }\end{array}$ & $8 \cdot 8$ & $6 I \cdot 3$ & 14.4 & $4 \cdot 00$ & $4 \cdot 52$ & $0.35^{2}$ \\
\hline Total & $14 \cdot 4$ & 一 & - & - & 一 & 0.437 \\
\hline
\end{tabular}

Girard's researches, show the contribution made to the total nitrogen of the grain by different 'offals' discarded in the milling of white flour from an average sample of wheat containing $2.2 \%$ of nitrogen, or about $13 \%$ of protein. Girard estimated that the aleurone contributes about $16 \%$ of the nitrogen of the grain and nearly $9 \%$ of the total weight. This seems a high figure considering that this layer consists of a single layer of cells, but more recent observations quoted by Booth, Carter, Jones \& Moran (I94r), and our own measurements of the volume of the aleurone layer, indicate that Girard's estimate was not excessive.

The germ is usually stated to contribute rather less than $2 \%$ of the total weight of the kernel, the values given varying from $\mathrm{I} \cdot \mathrm{O}$ to $2 \cdot 5$, but the amount will depend on how much of the scutellum is removed along with the embryo (Moran \& Drummond, I945). Its contribution of about $4 \%$ to the total nitrogen of the grain is, therefore, relatively small.

The proteins contained in bran were investigated by Jones \& Gersdorff (1923, 1925). They separated an albumin, a globulin and a prolamin from clean bran in quantities sufficient to account for $86 \%$ of the total nitrogen; of the total protein extracted, $27 \%$ was albumin, $22 \%$ globulin and $51 \%$ prolamin. They made a partial analysis of these and found that they differed in elementary composition and contained higher proportions of the essential amino-acids, arginine, lysine and tryptophan, than the proteins of the endosperm (see also Murphy \& Jones, 1926). The bran globulin had a lysine content of about i $\%$, a value which has only been exceeded by that of $\beta$-lactoglobulin (see Block \& Mitchell, I946). These observations of Jones \& Gersdorff 
on the high amount of some of the essential amino-acids in bran proteins have recently been confirmed and extended by Stokes, Gunness, Dwyer \& Caswell (1945) and Barton-Wright \& Moran (I946), who estimated the content of all the essential aminoacids in the mixture of proteins contained in different fractions of the wheat grain by microbiological methods. The significance of their results for the nutritive value of bran obviously depends on the extent to which these proteins are available to the animal since they are enclosed in thick-walled aleurone cells. With the ruminant this presents little difficulty, as the bran is retted and the cell walls digested by the action of the rumen bacteria, but in man and non-ruminating animals this does not occur until the food residues reach the caecum and large intestine.

Earlier work on the nutritive value of wholemeal bread led to the conclusion that the bran was digested to a considerable, if variable, extent by man, and that much of its nitrogenous material was made available provided it was well diluted by the other constituents of the diet (Rubner, r883; Hindhede, I923; Johansson, I9I7; Wiegner, I9I8).

The only experiments we have discovered in the literature, in which bran was eaten by human beings and its digestibility investigated, are those of Girard (1884) and of Borgström (I94I). Girard experimented upon himself and concluded that the degree of digestibility was negligible. Borgström, from experiments on four human subjects, decided that nearly $90 \%$ of the nitrogen was absorbed. The reason for such discordant results is not obvious. Individuals appear to differ in the extent to which they can cope with bran owing to its laxative properties, especially if the bran is taken in large quantities. More consistent estimates of the digestible nitrogen in wheat bran have been derived from investigations on the relative digestibility of the nitrogen in wholemeal and white flour in which the diet was composed largely of bread (Rubner, I883; Macrae, Hutchinson, Irwin, Bacon \& McDougall, I942); these indicate that about $60 \%$ of the nitrogen of bran is absorbed during passage through the human gut.

Higher figures, ranging from 72 to $90 \%$, have been obtained in in vitro tests in which gastric and intestinal enzymes were employed (Rubner, I 883; Borgström, I94I ; Booth \& Moran, I946).

The previous work on the digestibility of bran proteins is described in greater detail below (p. I66), together with our own observations. These were confined to in vitro tests and to observations on the fate of bran tissues and of the nitrogen in them during their passage through the alimentary canal of rats and pigs. In so far as the former were a repetition of those of previous workers, they yielded confirmatory results.

The nutritive value of bran proteins was investigated by Osborne \& Mendel (I9I9), who showed that the proteins of bran possessed a higher growth-promoting capacity for young rats than those of white flour, a result later confirmed by Murphy \& Jones (I926) and by 'Hove, Carpenter \&- Harrel (I945). The 'protein efficiency ratio' (P.E.R. $=$ g. weight increase/g. protein ingested) found for bran proteins was about 2.0 and for white flour from 0.5 to $\mathrm{I} \cdot 2$, according to the type employed. In recent studies from this laboratory (Chick, I942; Chick, Copping \& Slack, I946) it was shown that the growth-promoting value for the young rat of the mixture of proteins in whole-wheat 
flours (100\% extraction) and of that in National flours of $85 \%$ extraction was, respectively, about 20 and $16 \%$ higher than that of the proteins contained in white flour ( $70 \%$ extraction) milled from the same grist.

In the few measurements that have been made of the biological value of proteins by the method of Karl Thomas, as modified by Mitchell for use with growing rats (Mitchell, 1924a, $b$; Mitchell \& Carman, 1924), values of 57 and 47 , respectively, were found for the nitrogen of bran and white flour by Klein, Harrow, Pine \& Funk (1926), and of 74 and 84 , respectively, for bran and pollard by Marais \& Smuts (1940). Better nitrogen retention from wheat flours containing bran fractions was shown by Jacquot and his colleagues both with rats and human subjects (Guillemet \& Jacquot, 1944; Jacquot, Trémolières, Guillemet \& Erfman, 1944).

Since the nitrogen of bran supplies about one-fifth of the total present in wheat and is largely derived from the aleurone layer, it was our desire to study the nutritive value of bran proteins in the separated condition. This we were unable to do owing to the difficulties encountered in the efforts to obtain the quantity needed for a biological test. We have been able, however, to estimate the value of these proteins indirectly by observing the effect produced on the protein efficiency ratio by the addition of bran to white flour in varying proportions. These experiments are reported below (p. I74), and indicate that the P.E.R. of the mixed proteins of bran is approximately twice that of the proteins in white flour of $70 \%$ extraction.

\section{EXPERIMENTAL}

\section{AMOUNT OF THE ALEURONE LAYER}

Booth et al."(194I) concluded that average figures for percentage weight of the kernel were: $6-7$ for the aleurone, 4 for the pericarp, $2 \cdot 5$ for the testa and nucellus, 2.5 for the germ (scutellum and embryo proper) and 85 for the endosperm. We attempted to confirm the figures for aleurone and pericarp by mensuration.

If the wheat grain is regarded as an ellipsoid, its volume can be ascertained with close approximation from measurement of its diameters along the major and minor axes, the volume being expressed as $\frac{4}{3} \pi \times \frac{1}{2} a \times \frac{1}{2} b \times \frac{1}{2} c$, where $a, b$ and $c$ represent these diameters. This assumption was tested by direct measurement of the volume by displacement of water, and it was found that the direct measurement and calculated volumes agreed within $4 \%$ and generally less, when the average measurements from twenty grains were used for the calculation and the same twenty grains were used for the measurement by displacement.

To calculate the volume of the aleurone layer it was necessary to know the mean thickness of the pericarp and of the aleurone at the same state of hydration as that at which the volume of the whole grain was computed. We employed grains of wheat which had been soaked in water for $24 \mathrm{hr}$., at the end of which time they had doubled their original volume and were also in a suitable condition for sections to be cut either by hand or with a freezing microtome. 'The thickness of both aleurone and pericarp was measured with a micrometer eyepiece at a magnification of 60 diam., and the mean thickness of each was estimated from observations in different situations. 
For simplification our measurements included the testa and nucellus with the three layers of the pericarp proper. Assuming for the moment that the coats cover the surface of an ellipsoid, subtraction of the mean thickness of the pericarp from the 'half diameters' $\frac{1}{2} a, \frac{1}{2} b, \frac{1}{2} c$ in the above formula would give the volume of the grain without the pericarp, and subtraction of the combined thickness of both pericarp and aleurone, the volume of the grain without both these layers. The difference between these two volumes would be the volume of the aleurone.

These are not the true values, however, because in the grain both aleurone and pericarp are tucked in at the raphe and extend half-way across the transverse section of the grain. By measuring the extension produced by this infold the necessary correction to be applied was found to amount to an increase of about $25-30 \%$ and, in the volumes of the pericarp and aleurone given below, $25 \%$ has been added to the geometrical calculations. The weakest point in our computation of the volume of the aleurone and pericarp is the estimation of the mean thickness of the two coats. Neither of them is quite uniform in thickness, and a difference of about $0.005 \mathrm{~mm}$. in the estimate of the mean thickness of either makes a difference of about $10 \%$ in the calculated volume.

From six observations on grains of English wheat, of average volume $64.6 \mathrm{cu} . \mathrm{mm}$. when soaked, the mean thickness of both the aleurone layer and of the pericarp was estimated to measure $0.055 \mathrm{~mm}$. The percentage of the total volume calculated for the pericarp + testa + nucellus was $8 \cdot 5$ (range $7 \cdot 9-9 \cdot 8$ ), and for the aleurone layer $7 \cdot 6$ (range $7 \cdot 5-7 \cdot 8$ ). From the few observations made on a sample of Canadian wheat (variety Manitoba no. 2), of which the average volume of the grains was only $18.3 \mathrm{cu} . \mathrm{mm}$. in the dry state and $39.8 \mathrm{cu}$.mm. when soaked, the proportion of the total volume occupied by the pericarp and seed coats was $9.8 \%$ and by the aleurone $8.7 \%$, indicating that the proportion of starchy endosperm was greater in the plump English grains than in the sample of Canadian wheat. No great accuracy is claimed for these results, but they suffice to show that Girard's (1884) conclusion, that the aleurone together with the nucellus amounted to $8-9 \%$ of the weight of the grain, was a reasonable one. Recently, J. C. Hinton, after separation by dissection of the fibrous and aleurone layers of a sample of wheat, found that they amounted respectively to 8 and $7 \%$ of the weight of the grain (see Booth \& Moran, I946). From our observations, the proportion of the volume of the aleurone to the total volume is less, and that of the pericarp greater, than the corresponding values found by Girard for their relative weights; our figure agrees, however, with that found by Hinton. Girard concluded that the weights of aleurone and of pericarp + testa were in a ratio of about 40 to 60 ; our estimates of their volumes would give a ratio nearer 47 to 53 . Girard included the nucellus, and probably the unpigmented layer of the testa, with the aleurone layer because he could not separate them from it by dissection, whereas we have reckoned the nucellus along with the pericarp and testa. Girard's measurements would thus add about $10 \%$ to the weight of the aleurone and deduct a similar amount from the pericarp. 
DIGESTIBILITY OF BRAN AND AVAILABILITY OF ITS NITROGENOUS CONSTITUENTS

\section{Previous work}

Girard (1884) prepared himself for 2 days by a diet of fluids or of foods so finely divided as to pass through a fine sieve (no. 18 ), after which he consumed, in addition, a single dose of $5.67 \mathrm{~g}$. of bran. This had previously been soaked in warm water, which had removed about $16 \%$ of the original dry matter. The faeces excreted during the succeeding 5 days were passed through a still finer sieve. After this period no solid residue was found to be retained on the sieve. The total weight of the sieved residue, after washing and drying, was $5.19 \mathrm{~g}$., indicating that only $0.48 \mathrm{~g}$. or $8.5 \%$ of the weight of the ingested bran had been absorbed. From the nitrogen content of the residue Girard calculated that $82 \%$ of the nitrogen was not absorbed and, since the aleurone layer provides about $80 \%$ of the total nitrogen of the bran, he concluded that most of these cells must have resisted attack in the human alimentary tract. He found support for this view by microscopical detection of aleurone cells in the bran particles recovered from the faeces.

In Borgström's (194I) tests the subjects were prepared by a 5 days' period on a low-nitrogen diet of sugar and cream with ascorbic acid and vitamin $B_{1}$. During a subsequent period of 5 days they received daily, in addition, $30 \mathrm{~g}$. bran which had been heated to $97^{\circ}$ for $\mathrm{I}$ hr. By this addition the daily nitrogen intake was increased from 0.3 to about $\mathrm{x} \cdot 0 \mathrm{~g}$. The increase in faecal nitrogen, attributed to undigested bran, was found to be $\circ . \mathrm{g}$., and it was concluded that about $88 \%$ of the nitrogen of the bran had been absorbed.

The divergence between the results of Girard and those of Borgström is great. Girard's experiments, in which raw bran was swallowed, do not perhaps provide a fair parallel to the eating of boiled bran or bran as included in wholemeal bread, for during the raising and cooking of the dough the moist, warm conditions may cause bursting of cell walls and escape of enzymes and of protein from the cells, including those of the aleurone layer. Moreover, the figures summarized below, found by other workers for digestibility of the nitrogen in wholemeal breads of different types, are in sharp contrast to the results of Girard.

Rubner ( 1883 ), from comparison of the digestibility of the nitrogen in wholemeal and white breads, concluded that two-thirds of the nitrogen of the bran was assimilated. He checked this result by another method. By washing and sieving the 'wheatmeal' bread he obtained from $100 \mathrm{~g}$. dry weight, $9 \mathrm{~g}$. of dry, clean bran, of nitrogen content $4 \%$. The composition of the faeces corresponding to the ingestion of $100 \mathrm{~g}$. (dry weight) of the 'wheatmeal' bread was then compared with that of the faeces corresponding to $9 \mathrm{I} \mathrm{g}$. of the white bread (dry). In the former case an extra $0.36 \mathrm{~g}$. nitrogen was ingested derived from the $9 \mathrm{~g}$. of bran present. The faeces, however, contained only $0.14 \mathrm{~g}$. nitrogen in excess of that present in those passed from $9 \mathrm{I} \mathrm{g}$. of the white bread. Therefore, $0.22 \mathrm{~g}$. nitrogen, or two-thirds of the nitrogen of the bran, must have been absorbed in its passage through the gut.

In the trials of Macrae et al. (1942) the nitrogen of white bread (from flour of 
$73 \%$ extraction) was found to have an average digestibility for six human subjects of $91 \cdot 1 \%$ and that of wholemeal bread (from flour of $100 \%$ extraction) one of $85.5 \%$. The figures for the energy absorbed were 96 and $87 \%$, respectively. We have calculated the nitrogen absorbed from bran in these experiments, which are particularly suitable for the purpose as the flours were derived from the same grist, and the figures for digestibility were the means of those obtained with six individuals. Assuming that $15 \%$ of wholemeal flour consists of bran of nitrogen content $3.3 \%, 1.5 \%$ of germ of nitrogen content $6.7 \%$ (see Table $\mathrm{r}$ ), all of which is completely digested, and the remainder of white flour, the calculated digestibility of the nitrogen in the bran is found to be $67 \%$, a figure agreeing with that obtained by Rubner.

Eckstein \& Vogel (1942) investigated the digestibility of whole-grain breads (rye and wheat) of various types by a method reminiscent of that employed by Girard. The branny particles were separated by rubbing up the breads with water to a uniform suspension which was passed through a sieve of standard small mesh until the filtrates were clean. The same process was applied to bread which had been well chewed in the mouth (Mundkleie) and also to the faeces passed by the same human subject after ingestion of the bread. Microscopical examination showed that the branny particles recovered from the faeces (Kotkleie), in contrast to those recovered from the mouth, consisted almost entirely of pericarp; only a few aleurone cells could be detected, and of these the contours were not well marked and the contents no longer included fat. Analyses of corresponding residues showed that $92.4 \%$ of the nitrogen and $82.4 \%$ of the fat of the Mundkleie had disappeared during passage through the gut.

The mass of evidence afforded by the above experiments indicates that, when wholemeal bread is consumed, a large proportion of the protein contained in the outer layers of the grain is utilized by the human subject. The figures cited for digestibility of nitrogen refer to apparent digestibility, calculated on the assumption (only partly true) that the nitrogen passed in the faeces represents the undigested nitrogen of the food. Since the faeces also contain endogenous nitrogen derived from gastric and intestinal secretions, figures for true digestibility will be higher.

Rubner ( $188_{3}$ ) found that, when the cleaned branny particles (Hïlsen) obtained from wheatmeal flour were treated with pepsin in $4 \% \mathrm{HCl}$ for $17 \mathrm{hr}$. at $38-40^{\circ}$, the nitrogen content of the residue derived from bran originally containing $4.9 \%$ was reduced to $\mathrm{I} \cdot 45 \%$ and, after a further $\mathrm{I} 7 \mathrm{hr}$., to $0.94 \%$, i.e. nearly three-quarters of the original nitrogen had been rendered soluble. Action of pancreatic juice caused a rapid diminution in the opacity of the contents of the aleurone cells and sometimes complete clearance, but on other occasions the cell contents appeared unaltered after $34 \mathrm{hr}$. Rubner attributed the slowness of these actions, as well as the relatively low digestibility of the bran proteins in the human gut, to the difficulty of passage for the enzymes through the cell walls of the aleurone in which the greater part of the nitrogen is contained.

In Borgström's (194I) experiments about one-third of the nitrogen of bran, ground to pass a sieve of mesh $\mathrm{I} \mathrm{mm}$., was rendered soluble by pepsin at $\mathrm{pH} \mathrm{I} \cdot 7$ in $2 \mathrm{hr}$. at $37^{\circ}$, and about one-half by the action of trypsin at $\mathrm{pH} 8 \cdot \mathrm{r}$. When the bran was exposed to the action of human gastric juice for $3 \mathrm{hr}$. followed by that of duodenal juice for 
$2 \mathrm{hr}$, $7 \mathrm{r} \%$ of its nitrogen was dissolved. If, however, each of these stages was prolonged to 4 days, with repeated renewal of the digestive fluids, $60 \%$ of the dry matter and $90 \%$ of the nitrogen went into solution.

Booth \& Moran (1946) subjected a sample of finely ground bran, which had been cleaned as far as possible from adherent endosperm, to the following successive operations at $37^{\circ}$ : warm water $30 \mathrm{~min}$; ptyalin $30 \mathrm{~min}$; pepsin $4 \mathrm{hr}$. at $\mathrm{pH} 2 \cdot 0$; pancreatic enzymes $\mathrm{I} 6 \mathrm{hr}$. at $\mathrm{pH} 8 \cdot 0-8 \cdot 5$. As a result of these operations they found that $72 \%$ of the nitrogenous material originally present had been digested. When the bran was previously cooked the proportion of nitrogen digested was $65 \%$. The loss in weight resulting from the above treatment, representing the proportion which would become available to animals, was $29 \%$ for the uncooked, and $34 \%$ for the cooked, sample.

\section{Present experiments}

In the present work the digestion of the proteins of wheat bran was studied by in vitro methods, so that the results could be compared with the changes observed to take place in bran on its passage through the alimentary canal of the rat and the pig.

\section{(a) Experiments in vitro}

A sample of commercial bran (bran A) containing $2.6 \%$ nitrogen on the dry weight was subjected to the following series of treatments designed to reproduce the course of events taking place in the mammalian gut. About $2 \mathrm{~g}$. bran of known moisture content were weighed into a large test-tube, about $20 \mathrm{ml}$. of distilled water added, and the tube placed in a water-bath. The water in the bath was brought to the boil, kept there for Io min. and then allowed to cool before the tube was removed. Its contents were filtered through a hardened filter-paper, the residue washed well with hot water, scraped off the paper, dried at $110^{\circ}$ and weighed. After a portion of the residue had been taken for nitrogen estimation, the remainder was put into a flask with $10 \mathrm{ml}$. water and $10 \mathrm{ml}$. human saliva and incubated at $40^{\circ}$ for $\mathrm{I} \mathrm{hr}$. It was then filtered, the residue washed and a portion removed for dry-weight and nitrogen estimation as before. The remainder was kept at $40^{\circ}$ with a $\mathrm{I} \%$ solution of pepsin in $\mathrm{N} / 20-\mathrm{HCl}$ for about $\mathrm{I} 8 \mathrm{hr}$. Of the residue from the pepsin digestion a portion was kept for analysis and the remainder incubated for $18 \mathrm{hr}$. at $40^{\circ}$ in a trypsin solution maintained at $\mathrm{pH} 8.0$ with a phosphate-buffer mixture. Finally the residue from the trypsin solution was washed, dried and its nitrogen content determined. In order to obtain consistent results it was found necessary to carry out all the above treatments successively on the same sample of bran.

The results of four such experiments are given in Table 3. They show that, as a result of these successive digestions, about one-half of the total solids and threequarters of the nitrogen of the original bran were digested, results very close to those obtained by Rubner (r883), Borgström (r94I) and Booth \& Moran (r946) (see above, p. 167). About one-quarter of both the solids and the nitrogen was soluble in hot water. Ptyalin removed only a small proportion of solids derived from starch still 
adherent to the bran. Treatment with pepsin and $\mathrm{HCl}$ removed about $10 \%$ of the solids and about $25-30 \%$ of the nitrogen, while the trypsin digested $4-6 \%$ of the remaining solids and $x_{3}-23 \%$ of the remaining nitrogen. In one experiment (Exp. 4), in which digestion with pepsin was omitted, the results showed that by the action of trypsin alone almost as much solution took place, both of total solids and of nitrogen.

Table 3. Loss of weight and nitrogen when $100 \mathrm{~g}$. bran $A$, containing $2.6 \%$ nitrogen, were treated successively with: boiling water for 10 min., ptyalin at $40^{\circ}$ about I $\mathrm{hr}$., pepsin, $\mathrm{r} \%$ solution in $\mathrm{N} / 20-\mathrm{HCl}$, for $\mathrm{I} 8 \mathrm{hr}$., trypsin at $\mathrm{pH} 8.0$ for $18 \mathrm{hr}$.

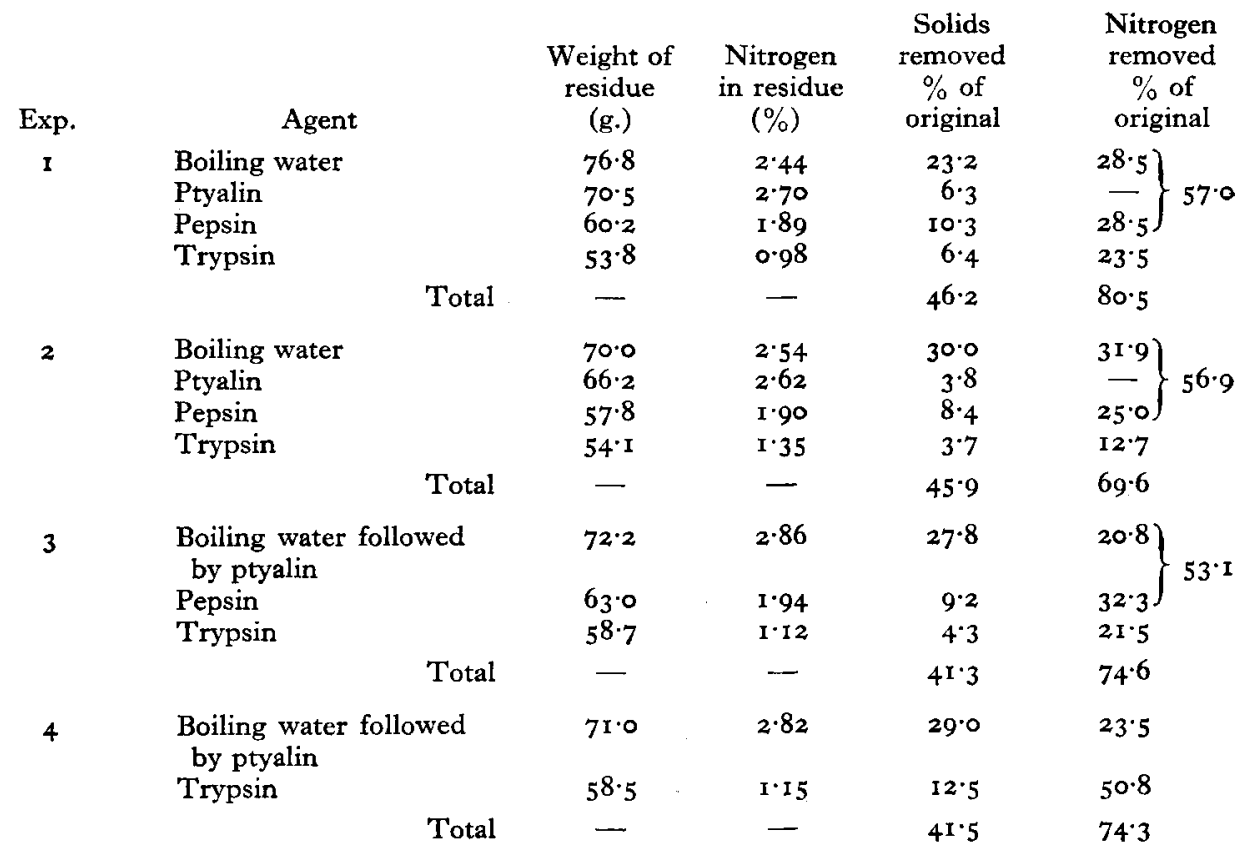

After each stage in the procedure, the bran residue was examined microscopically. The preliminary treatment with boiling water caused little change in the appearance, except that in some cases a small amount of the aleurone layer had become detached from the pericarp. After digestion with ptyalin all starch had disappeared, but the bran was not otherwise affected. After treatment with pepsin and $\mathrm{HCl}$ the aleurone layer was seen to be separated from the pericarp and frequently broken into small pieces; the cell contents were less opaque, and in some cases the fine particles of fat had coalesced to form one large fat globule. The degree of disintegration of the aleurone cells and the effect on their constituents after trypsin digestion varied in the different experiments. The aleurone cells were often in groups of two or three or small aggregates; the opaque contents had disappeared, the particles of fat had coalesced and the cell walls had become more transparent. It seemed as if the protein contents of the cell had been digested by the trypsin, leaving behind the nucleus and fat. In the same specimen, however, some aleurone cells were still found with contents which appeared to have undergone little alteration. 


\section{(b) Animal experiments}

In the following experiments an attempt was made to follow more precisely the fate of the aleurone cells during their passage through the alimentary tract and to determine the degree of digestion of the nitrogen of the bran at different stages.

\section{Experiments with rats}

Rats, about $\mathrm{I}_{5} \mathrm{O}$. in weight, were given the following diet, in which commercial bran provided the only source of nitrogen: bran A, ground to 'medium' fineness, 7 I parts, pure maize starch 22, hardened arachis oil 4, salt mixture (McCollum's no. I85) 2, cod-liver oil I. To each $100 \mathrm{~g}$. of the mixture $100 \mathrm{ml}$. water were added and the whole steamed for about $\mathrm{I}$ hr. The diet formed a homogeneous cake which was convenient to feed. One $\mathrm{ml}$. daily of a protein-free yeast extract was given separately to each rat to provide adequate amounts of $\mathbf{B}$ vitamins.

Microscopic examination of the contents of different portions of the alimentary canal. Rats which had received this diet each morning for 3 days were killed at about I a.m., care being taken that sufficient food in excess of appetite had been given on the previous day. The alimentary canal was removed and the stomach, duodenum, ileum, caecum and large intestine separated. The contents of each portion were removed and examined microscopically and the undigested bran analysed for nitrogen content. The contents of the different regions of the alimentary canal were rubbed up in water to form a fine emulsion and centrifuged at low speed. The supernatant cloudy fluid containing bacteria, some other small particles and soluble nitrogenous matter, was removed and the process repeated until it became clear. The washed residue was then dried and its nitrogen estimated.

In the stomachs of seven of nine rats the bran had undergone little apparent change. In that of two rats, however, the contents of the cardiac portion presented a picture of disintegration and solution which was not seen in the gut of the other seven rats until the caecum was reached. The different layers of the pericarp had become separated and the aleurone layer detached. Some of the aleurone cells were empty, others contained only an occasional fat globule. The $\mathrm{pH}$ of the contents was 6.5 and bacteria.were abundant, indicating that the food had sojourned in the cardiac portion for some considerable time.

In the ileum the aleurone layer was usually separated from the pericarp and broken up. The contents of its cells were less opaque, contracted in size and in some cases absent, leaving empty pieces of honeycomb. In the caecum and rectum the process had gone further; in the latter little of the remnants of the aleurone layer could be recognized.

The appearance of bran after subjection to in vitro or in vivo action of gastric and intestinal enzymes was much the same. In both cases the digestion of the contents of the aleurone layer, begun by the pepsin, was completed by the trypsin, but, during the passage through the gut of the living rat, there was more complete separation of the different layers of the pericarp and more general disintegration, doubtless due to the additional action of bacteria. 
Nitrogen content of the residues recovered from different portions of the rat's gut. In Table 4 are given the results of five experiments. In three of these the rats were fed on bran A, the sample used for the in vitro experiments (see Table 3), and in the remaining two on bran $\mathrm{B}$, the sample employed in the test with pigs to be described later.

Table 4. Nitrogen content of bran residues recovered from different portions of the rat's gut expressed as percentage of dry weight

\begin{tabular}{|c|c|c|c|c|c|c|c|}
\hline & \multicolumn{4}{|c|}{$\begin{array}{l}\text { Nitrogen content on dry weight } \\
\text { (bran A } 2.60 \% \text {; diet fed } 1.97 \% \text { ) }\end{array}$} & \multicolumn{3}{|c|}{$\begin{array}{l}\text { Nitrogen content on dry weight } \\
\text { (bran B } 2.34 \% \text {; diet fed } \mathrm{r} \cdot 88 \% \text { ) }\end{array}$} \\
\hline & Rats & Rat & Rat & Average & Rats & Rats & Average \\
\hline Portion of gut & $A+B$ & $\mathrm{Y}$ & $\mathrm{Z}$ & & $12+13$ & $14+15$ & \\
\hline Stomach & $2 \cdot 13$ & $2 \cdot 04$ & - & $2 \cdot 08$ & $1 \cdot 48$ & $r \cdot 88$ & +68 \\
\hline $\begin{array}{l}\text { Small intestine: } \\
\text { Upper } \\
\text { Lower }\end{array}$ & 二** & I. IO & $\begin{array}{r}\mathrm{r} \cdot 69 \\
\mathrm{I} .08\end{array}$ & $\begin{array}{l}1.39 \\
1.08\end{array}$ & $\begin{array}{l}\mathrm{I} \cdot \mathrm{II} \\
0 \cdot 76\end{array}$ & $\begin{array}{l}\text { I.05 } \\
0.82\end{array}$ & $\begin{array}{l}\text { I.08 } \\
0 \cdot 79\end{array}$ \\
\hline $\begin{array}{l}\text { Caecum } \\
\text { Rectum }\end{array}$ & $\begin{array}{l}I \cdot 12 \\
I \cdot 13\end{array}$ & $\begin{array}{l}0.95 \\
0.99\end{array}$ & $\begin{array}{l}x \cdot 22 \\
1 \cdot 08\end{array}$ & $\begin{array}{l}\text { I. I0 } \\
\text { I.07 }\end{array}$ & $\begin{array}{l}0.92 \\
0.83\end{array}$ & $\stackrel{0.74}{-}$ & $\begin{array}{l}0.83 \\
0.83\end{array}$ \\
\hline Faeces & $0.82 \dagger$ & 0.99 & $I \cdot I I$ & 0.97 & - & 0.89 & 0.89 \\
\hline
\end{tabular}

* Rats fed at 9.30 a.m., after $24 \mathrm{hr}$. fast, killed at I I a.m. to ensure a full stomach; hence no figures available for small intestine.

+ Figure for rat $\mathrm{A}$ only.

In spite of the variations that might have been expected, consistent results were obtained. The average nitrogen content of the residue from bran $A$ recovered from the stomach was $2.08 \%$ (rats A, B and Y, Table 4). This figure may be compared with the value of about $1.9 \%$ found in the bran after treatment with hot water, ptyalin and pepsin in vitro and presumably represents the removal of a similar amount, about $55 \%$, of the original nitrogen (see column 6 , Table 3 ). Similarly, the average figures obtained for the nitrogen content of the branny residues obtained from the rectum $(\mathrm{I} \cdot 07 \%)$ and faeces $(0.97 \%)$ are not inconsistent with the average of $\mathrm{I} \cdot 15 \%$ obtained for the residue after treatment with hot water, ptyalin, pepsin and trypsin, and correspond to a loss of about $67 \%$ of the original nitrogen. The figures for the residues obtained from rats 12 and $I_{3}$ and rats $I_{4}$ and $I_{5}$ fed on bran $B$ are all slightly lower, a fact probably accounted for by the lower nitrogen content of the original bran.

A figure of the same order was obtained by Osborne \& Mendel (1919), who fed rats on a diet containing $55 \%$ of commercial bran with salt mixture, starch, butterfat and lard, and found that $75-80 \%$ of the total food and $70-75 \%$ of the nitrogen were utilized.

\section{Experiments with pigs}

Due to the kindness of $\mathrm{Mr} \mathrm{R}$. S. Comline we obtained stomach and intestinal contents from pigs which had been fed on a sample of the bran $B$ which was used for the diet of rats $12-15$ (Table 4 ).

The bran had been finely ground and was in very small pieces, but the aleurone 
layer was still firmly adherent. It was mixed with a little water before feeding and chromium oxide was added as a faecal marker. In some cases the bran had been heated in an oven. 'The pigs, which were $36-48 \mathrm{lb}$. in weight, were usually killed $2-3 \mathrm{hr}$. after their last meal. The digestion of the aleurone layer was found to have proceeded further in the stomach than was usual with the rat. The layer remained adherent to the pericarp, but the cell contents had become lighter in colour and less dense, and oil drops were almost invariably present. In the duodenum the cell contents were still clearer and separation of the layer from the pericarp had taken place. In the caecum and rectum aleurone cells were seldom to be seen.

Table 5. Nitrogen content of washed bran residues recovered from different portions of the pig's gut expressed as percentage of dry weight

(Bran B percentage nitrogen on dry weight 2.34 ; for the washed bran $1 \cdot 85$.)

\begin{tabular}{|c|c|c|c|c|}
\hline Portion of gut & Pig $I^{*}$ & Pig $2^{*}$ & Pig $3 \dagger$ & Average \\
\hline $\begin{array}{l}\text { Stomach } \\
\text { Duodenum }\end{array}$ & $\begin{array}{l}1 \cdot 12 \\
0.94\end{array}$ & $\begin{array}{l}0.97 \\
0.69\end{array}$ & $\begin{array}{l}1.14 \\
0.86\end{array}$ & $\begin{array}{l}1.08 \\
0.83\end{array}$ \\
\hline Small intestine & $\begin{array}{l}0.94 \\
0.89\end{array}$ & 0.63 & 0.77 & 0.76 \\
\hline Caecum & 0.76 & 0.72 & 0.73 & 0.74 \\
\hline Colon: ist loop & $0.6 I$ & 0.50 & 0.64 & 0.58 \\
\hline and loop & 0.62 & 0.47 & 0.63 & 0.57 \\
\hline Rectum & 0.66 & $0.5 \mathrm{I}$ & 0.54 & 0.57 \\
\hline
\end{tabular}

The results of chemical analyses of the bran residues recovered from the different portions of the gut were consistent with the microscopic appearances (Table 5). Before analysis these residues were well washed in the same way as those recovered from the intestine of the rat. The average nitrogen content of the residue recovered from the stomach was $\mathrm{r} .08 \%$, and from the rectum $0.57 \%$ (dry weight), as against $\mathrm{r} .68$ and $0.89 \%$, respectively, for the rat (see Table 4 ). One may conclude that the nitrogen of the bran was more thoroughly digested by the pig than by the rat.

THE NUTRITIVE VALUE OF THE PROTEINS CONTAINED IN BRAN

\section{Previous work}

The convenient method of determining the nutritive values of proteins introduced by Osborne \& Mendel (see Osborne, Mendel \& Ferry, 1919) is the one that has been most generally used for the proteins of bran. Values are expressed as $\mathrm{g}$. weight gains of young growing rats/g. of protein consumed. The figure arrived at by this means has been designated the 'protein efficiency ratio' (P.E.R.) by Block \& Mitchell (I946), and we adopt this expression throughout this paper. When this method has been employed with due attention to certain conditions of the experiment, chief amongst which are that the protein under test be fed in adequate but not excessive amounts, that the diet provide sufficient energy and furnish all the necessary vitamins and that the observations be carried out for at least 5-6 weeks, consistent results have been obtained with isolated proteins. The determination of the P.E.R. presents difficulties, however, 
and may be frustrated when attempts are made to evaluate the nutritive value of the mixed proteins in a foodstuff. This is particularly so when, as in bran, the proteins are enclosed in dense tissues from which they are with difficulty and uncertainty extracted and the diet contains an excess of indigestible material. Under these circumstances the P.E.R. will be underestimated to a variable extent.

In their classical paper on the nutritive value of the wheat kernel Osborne \& Mendel (I9I9) described experiments with bran and with a patent white flour. On the bran diet only one of the four rats could cope with the excessive roughage, but this animal made satisfactory growth and the experiment gave a value of 2.0 for the P.E.R., whereas with patent flour the figure obtained was only 0.50 . Murphy $\&$ Jones (1926), using Osborne \& Mendel's method, were more successful in getting rats to grow on a diet containing $20 \%$ of fat and $10.5 \%$ of protein furnished exclusively by bran. They made an experiment with eight rats and continued it for 200-300 days. During the first 6 weeks the rats grew relatively well, the average weekly weight increase being $9 \cdot 7$ g. The range of the P.E.R. was $1 \cdot 55^{-2} \cdot 13$ with a mean of $\mathrm{I} \cdot 83$. In a similar experiment on a patent white flour with four rats, the results were more consistent, varying only from 0.79 to 0.99 , mean 0.88 . Hove et al. (1945), in work on the nutritive value of plant proteins, also used Osborne \& Mendel's method and expressed their results as a P.E.R. Among the cereal products investigated were wheat bran and various types of white flour. The diets contained approximately $10 \%$ of protein, and each experiment was made with ten rats and was continued for 6 weeks. The mean P.E.R. obtained for bran protein was 2.15 and for patent white flour 0.84 ; for a flour described as 'second clear' the P.E.R. was I.20.

The results of the above three sets of observers indicate that the P.E.R. of bran proteins is about $2 \cdot 0 \pm 10 \%$, and of white flour $\mathrm{I} \cdot 0 \pm 20 \%$, depending on the degree of extraction. The superior P.E.R. of bran protein was attributed by Murphy \& Jones (1926) to the fact, demonstrated by Jones \& Gersdorff (1925), that the bran proteins were much richer in certain essential amino-acids than those of white flour.

Guillemet \& Jacquot (1944) made metabolic tests on rats with diets composed of (a) white flour of $80 \%$ extraction; and mixtures of 75 parts of this white flour with 25 parts of the following fractions of bran: $(b)$ finer portions obtained by bolting; $(c)$ coarser portions; and $(d)$ a fraction rich in aleurone obtained by a technical process of rubbing wheat grains with emery surfaces after removing the pericarp. The retention of nitrogen was much higher on diet $(d)$ than on diet $(a)$, although the coefficient of digestibility of the former was lowered from 89 to $84 \%$; the results obtained with diets $(b)$ and $(c)$ were intermediate. In the human trials, made by Jacquot et al. (1944), bread provided the main source of nitrogen in the diet and the following three types were studied: (r) whole-wheat bread from flour of $100 \%$ extraction, (2) white bread from flour of $70 \%$ extraction and (3) bread made from a mixture of this white flour and the bran fraction rich in aleurone described under $(d)$ above in such proportion as to constitute a flour corresponding to about $80-85 \%$ extraction of the grain. With bread (3) the nitrogen retention was greater than on white bread. 


\section{Present experiments}

\section{Growth-promoting value of bran proteins for young rats}

Four experiments, each lasting 6-7 weeks, were made with diets in which the proportion of nitrogen was approximately constant and was derived, respectively, from white flour of $70 \%$ extraction (Exp. I), from a mixture of about 80 parts white flour and 20 parts commercial bran (Exp. 2), from a mixture in which about $5^{\circ}$ parts of the nitrogen were derived from white flour and 50 from bran (Exp. 3), and from bran alone (Exp. 4). In Exp. 5 the nitrogen of the diet was derived from a sample of outer endosperm (see p. 179).

The composition of the diets is set out in Table 6. The sample of white flour contained $70 \%$ starch and the bran $8.1 \%$; it was, therefore, estimated that there was about II \% starchy endosperm adhering to the bran.

Table 6. Particulars of the diets used in Exps. $1-5$, percentage of dry ingredients

\begin{tabular}{|c|c|c|c|c|c|c|}
\hline \multirow[b]{2}{*}{ Materials } & \multirow{2}{*}{$\begin{array}{c}\text { Nitrogen } \\
\text { content } \\
\text { on dry } \\
\text { weight } \\
(\%)\end{array}$} & \multicolumn{5}{|c|}{ Experiment } \\
\hline & & $\stackrel{\text { I }}{\text { Diet } 97}$ & $\stackrel{2}{{ }^{2}} 98$ & $\stackrel{3}{\text { Diet } 86}$ & $\stackrel{4}{\text { Diet }} 87$ & $\stackrel{5}{\text { Diet } 99}$ \\
\hline White flour & $2 \cdot 27$ & 92 & 75 & $37 \cdot 7$ & 一 & - \\
\hline Bran & $2 \cdot 47$ & - & 17 & $39 \cdot 5$ & 73.4 & 一 \\
\hline Outer endosperm & $2 \cdot 65$ & 一 & - & - & - & 79 \\
\hline Pure maize starch & 0.03 & - & $\cdots$ & $13 \cdot 2$ & $14 \%$ & 13 \\
\hline Hardened arachis oil & - & 5 & 5 & $7 \cdot 0$ & $8 \cdot 9$ & 5 \\
\hline Salt mixture* & - & 2 & 2 & $1 \cdot 7$ & $2 \cdot 2$ & 2 \\
\hline Cod-liver oil & - & I & $\mathbf{r}$ & 0.9 & $\mathbf{I} \cdot \mathbf{I}$ & $\mathbf{I}$ \\
\hline $\begin{array}{l}\text { Nitrogen content on dry } \\
\text { weight of diet }(\%)\end{array}$ & $\longrightarrow$ & $2 \cdot 01$ & $r \cdot 99$ & $x \cdot 80$ & $I \cdot 8 I$ & $2 \cdot 00$ \\
\hline $\begin{array}{l}\text { Protein derived from brant } \\
(\mathrm{N} \times 6.25)\end{array}$ & - & - & $2 \cdot 4$ & $5 \cdot 6$ & I I 3 & 一 \\
\hline $\begin{array}{l}\text { Protein derived from endo- } \\
\text { sperm }(\mathrm{N} \times 5.7)\end{array}$ & - & I I 9 & $9 \cdot 9$ & $5 \cdot 5$ & 一 & I I 9 \\
\hline Digestible protein (g.) & - & $10 \cdot 5$ & 10.2 & $8 \cdot 2$ & $7 \cdot 15$ & $10 \cdot 0$ \\
\hline Digestible energy (Cal.) & - & $436 t$ & $397 t$ & $3^{66} \S$ & $320 \S$ & $44 \mathrm{I} \ddagger$ \\
\hline
\end{tabular}

The amount of protein in the diets was between II and I2 \%. It was intentionally suboptimal and provided only about one-tenth of the total digestible energy in the diet. As the proportion of bran in the diet was increased, the total digestible energy/ roo g. of diet diminished from $430 \mathrm{Cal}$. in the white flour diet to $320 \mathrm{Cal}$. in the diet in which the whole of the protein was derived from bran. This handicap must be borne in mind in the interpretation of the results of the latter experiment.

The tests were made on young rats (Lister pied strain) weighing about $44-47 \mathrm{~g}$. They received the above diets shortly after weaning. Each rat was also supplied daily with I ml. of a protein-free yeast extract, equivalent to $0.5 \mathrm{~g}$. of dry yeast, to supply extra $B$ vitamins. The sexes were distributed evenly among the groups on the different 
diets, and the animals were allowed to feed ad lib. The rats were kept singly in cages fitted with open-mesh floors so that the faeces and unconsumed food which dropped through could be collected from the sheets of filter-paper placed underneath. An estimate could thus be made of the food intake and of the digestibility of the nitrogenous matter in the food. In the analyses and subsequent calculations, groups of 4-5 rats on the same diet were treated as one unit. Further details of the method have been published by Chick (1942).

Table 7. The economy of utilization for growth of the proteins contained in white flour (70\% extraction) and in mixtures of white flour and bran. Period of observation 6-7 weeks; 4-5 rats in each experiment

(All values expressed as average values/rat/week.)

\begin{tabular}{|c|c|c|c|c|c|c|c|c|c|}
\hline Exp. & $\begin{array}{l}\text { Source } \\
\text { of } \\
\text { protein }\end{array}$ & $\begin{array}{l}\text { Dry } \\
\text { food } \\
\text { eaten } \\
\text { (g.) }\end{array}$ & $\begin{array}{c}\text { Nitrogen } \\
\text { eaten } \\
\text { (g.) }\end{array}$ & $\begin{array}{l}\text { Protein } \\
\text { eaten*" } \\
\text { (g.) }\end{array}$ & $\begin{array}{c}\text { Weight } \\
\text { of } \\
\text { faeces } \\
\text { passed } \\
\text { (g.) }\end{array}$ & $\begin{array}{c}\cdot \\
\text { Nitrogen } \\
\text { in } \\
\text { faeces } \\
\text { (g.) }\end{array}$ & $\begin{array}{c}\text { Coeffi- } \\
\text { cient of } \\
\text { digesti- } \\
\text { bility† } \\
\text { (apparent) } \\
(\%)\end{array}$ & $\begin{array}{l}\text { Weekly } \\
\text { weight } \\
\text { increase } \neq \\
\text { (g.) }\end{array}$ & $\begin{array}{l}\text { Protein } \\
\text { efficiency } \\
\text { ratio }\end{array}$ \\
\hline I & Flour & $44^{\circ} 5$ & 0.90 & $5 \times 3$ & $I \cdot 34$ & 0.102 & $88 \cdot 6$ & $6 \cdot 2$ & $I \cdot 2 I$ \\
\hline 2 & $\begin{array}{l}\text { Flour } \frac{4}{8} \\
\text { Bran } \frac{1}{5}\end{array}$ & $56 \cdot 2$ & $x \cdot 12$ & 6.72 & 5.86 & 0.194 & $82 \cdot 7$ & $9 \cdot 7$ & $\mathrm{I} \cdot 44$ \\
\hline 3 & $\begin{array}{l}\text { Flour } \frac{1}{2} \\
\text { Bran } \frac{1}{2}\end{array}$ & $61 \cdot 7$ & $I \cdot I I$ & 6.66 & $12 \cdot 7$ & 0.280 & 74.9 & III 2 & I. 68 \\
\hline 4 & Bran & $5 \mathrm{I} \cdot 8$ & 0.93 & $5 \cdot 58$ & 18.6 & 0.340 & $63 \cdot I$ & 7.5 & $\mathrm{I} \cdot 34$ \\
\hline 5 & $\begin{array}{l}\text { Outer } \\
\text { endosperm }\end{array}$ & $49^{\circ} 0$ & 0.99 & $5 \cdot 63$ & $3 \cdot 76$ & 0.160 & 83.8 & $7 \cdot 4$ & $x \cdot 31$ \\
\hline
\end{tabular}

* For Exps. I and $5, \mathrm{~N} \times 5.7$; for Exps. 2, 3 and $4, \mathrm{~N} \times 6 \cdot 0$.

+ Nitrogen eaten - nitrogen in faeces Nitrogen eaten

I During periods in which food intake and digestibility were measured; in Exps. 1,2 and 5 during 5 weeks of the test; in Exps. 3 and 4 during the 2nd week.

The results of Exps. I-5 are summarized in Table 7, and the average growth rate of the rats receiving the different diets is shown in Fig. $\mathrm{I}$. The incorporation of bran in the diet had notable effects on the following factors.

\section{(a) Growth}

The rats in Exp. I on the diet in which all the protein was derived from white flour grew poorly, and the average weekly weight increase was only $5.6 \mathrm{~g}$., but in Exps. 2 and 3, as part of the protein derived from white flour was successively replaced by an equal amount of protein provided by bran, the growth of the rats improved. The average weekly weight increase in Exp. 2, in which one-fifth of the white flour protein was replaced by bran protein, was 8.8 , and in Exp. 3 , in which one-half of the white flour protein was similarly replaced by bran protein, it was $10.9 \mathrm{~g}$. When, in Exp. 4, the proportion of bran in the diet was increased until it provided all the nitrogen in the diet, however, the average weekly weight increase was $9 \cdot 1$ g. (see Fig. I). The probable reasons for the poor utilization on the all-bran diet will be given below. 


\section{(b) Intake of nitrogen}

The replacement of 20 and 50 parts of white flour by bran protein in Exps. 2 and 3 increased the consumption of food and nitrogen by about 30\%. In Exp. 4, however, in which all the protein was supplied by bran, the intake of food was only $16 \%$, and of nitrogen $3 \%$, in excess of that consumed on the white flour diet.

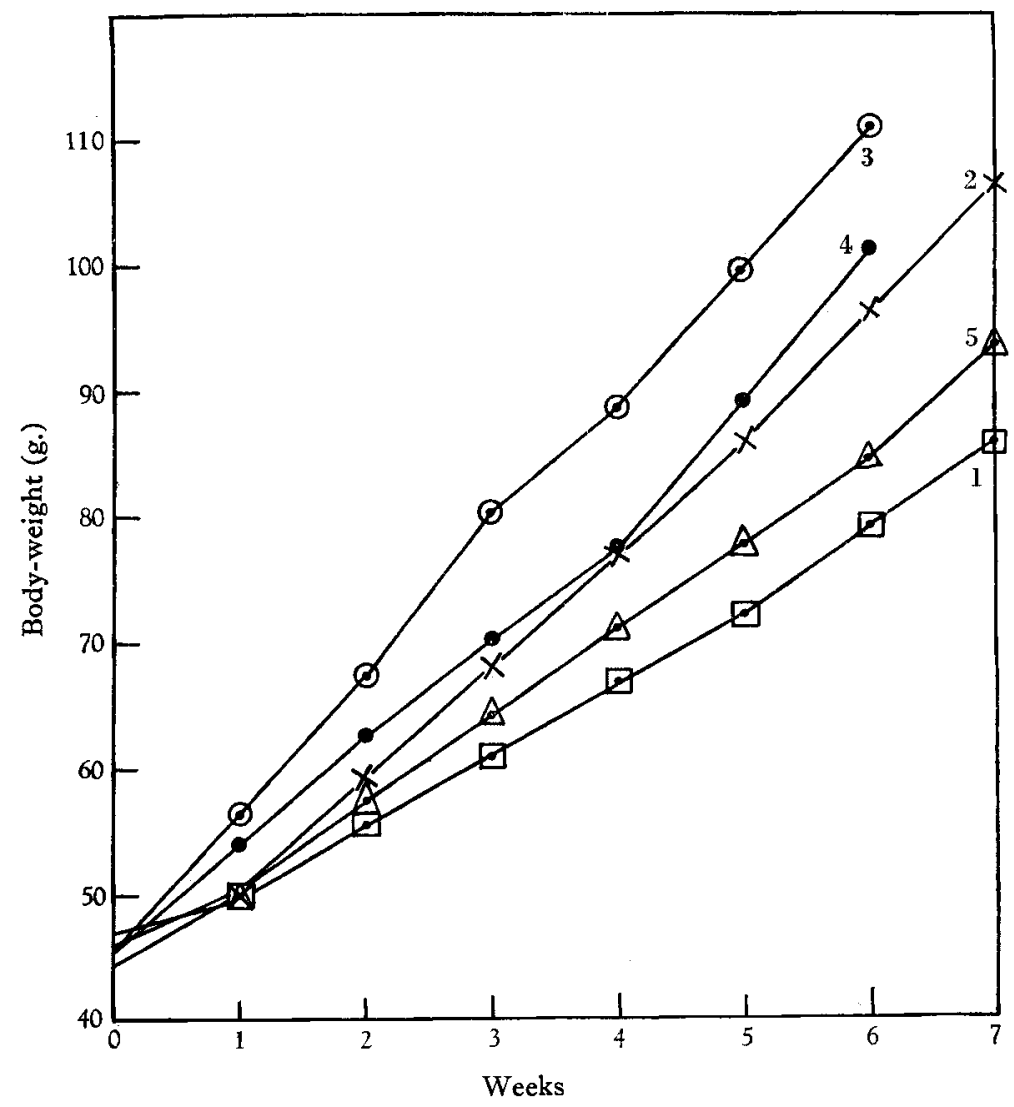

Fig. I. Average weight curves of four to five rats maintained from weaning on diets, otherwise complete, containing $\mathrm{I} \cdot 8-2 \cdot 0 \% \mathrm{~N}$ (on dry weight), derived from:

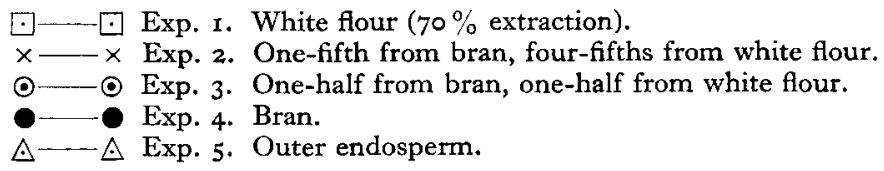

(c) Digestibility of the proteins in the mixtures

As the percentage of bran in the diet was increased, the digestibility of the nitrogen of the mixtures was progressively reduced from $88.6 \%$ with the white flour diet to $63 \cdot 1 \%$ with the all-bran diet. Intermediate values of 83 and $75 \%$ were obtained for the coefficients of digestibility of the diets containing 20 and 50 parts of bran protein resoectivelv. 
The value obtained for the digestibility of bran nitrogen in Exp. $4,63.1 \%$, was the same as that estimated from the results of the examination of the washed residues of the faeces of the rats fed on bran (see Table 4). Osborne \& Mendel (rgrg) and Marais \& Smuts (1940) obtained values of $75 \%$ from their experiments.

\section{(d) Protein efficiency ratio}

The P.E.R. of the proteins of the white flour used in the present investigation was I.2I. This is higher than the values recorded by Osborne \& Mendel (I9I9), Murphy \& Jones (1926) and Hove et al. (1945), all of whom used 'patent' flours of lower extraction rate. When, in our Exps. 2 and 3, 20 and 50 parts of the white-flour protein were replaced by bran protein, the P.E.R. rose to $\mathrm{I} \cdot 44$ and $\mathrm{I} \cdot 68$, respectively. The P.E.R. obtained for the proteins of the whole-bran diet, however, was only $\mathrm{r} \cdot 34$, a value considerably lower than that obtained by the three teams of workers just quoted, who obtained values of about 2.0 in experiments in which the whole of the nitrogen in the diet was derived from commercial bran. A re-examination of the conditions and results of our own Exp. 4 has led us to accept their figures as representing the real nutritive value of bran proteins for the following reasons. The sample of bran at our disposal contained only $2.47 \%$ nitrogen, and, in order to obtain a diet containing I $13 \%$ protein, it was necessary to incorporate $75 \%$ bran. This had the effect of reducing the digestible energy of the diet to $3.2 \mathrm{Cal} / \mathrm{g}$. It did not occur to us in time to remedy the defect by the inclusion of extra fat. Further, the young animals were unable to cope with the great excess of roughage brought in by the bran, and the digestibility of the nitrogen of the diet was reduced to $63 \%$. The low weight-gain/g. of protein eaten is capable of explanation on these two grounds, and it would be wrong to conclude that in Exp. 4 we had overstepped the most useful proportion of bran protein in the mixture. We have not repeated this experiment, since, in the meantime, Hove et al. (1945) published their excellent paper on the nutritive quality of plant proteins which included the measurement of the P.E.R. of a number of cereal products, amongst them that of wheat bran. Their experiments were carried out on ten rats for 6 weeks, the diet containing $9.9 \%$ protein, all of which was derived from commercial bran. Their sample of bran contained about $3 \%$ nitrogen, which made it unnecessary for them to include more than $62 \%$ in the diet. The mean value for the P.E.R. was found to be $2.15( \pm 0.09)$. We could not hope to better this experiment and have accordingly adopted $2 \cdot x_{5}$ as the P.E.R. of a mixture of bran proteins and endosperm proteins in the ratio $90: 10$, assuming that their sample of bran contained about $10 \%$ adherent endosperm.

If we adopt the figure of $2 \cdot 15$ for the P.E.R. of the proteins $(\mathrm{N} \times 6 \cdot 25)$ as existing in commercial bran and the figures found by us for white-flour proteins and for mixtures of these and bran protein in Exps. I, 2 and 3 , the improvement in P.E.R. is found to be roughly proportional to the percentage of bran proteins in the total protein of the mixtures. In these calculations allowance is made for the amount of endosperm protein in the white flour adherent to the bran. When the values obtained for P.E.R. are plotted against the proportion of proteins derived from clean bran, the experimental points fall on or about a straight line (see Fig. 2). This line does not meet the vertical axis 
at zero, since the white-flour proteins had a P.E.R. of I.2I. If $y=$ P.E.R. and $x=\%$ bran protein in the total protein, the equation to this line is $y=0.0104 x+1 \cdot 21$, from which the P.E.R. of the proteins as they exist in bran can be calculated to be about 2.25. This is a minimal value owing to the inability of the animal to extract the whole of the nitrogen from the indigestible matter in which it is included and to the fact that not all the nitrogen in the bran is protein nitrogen.

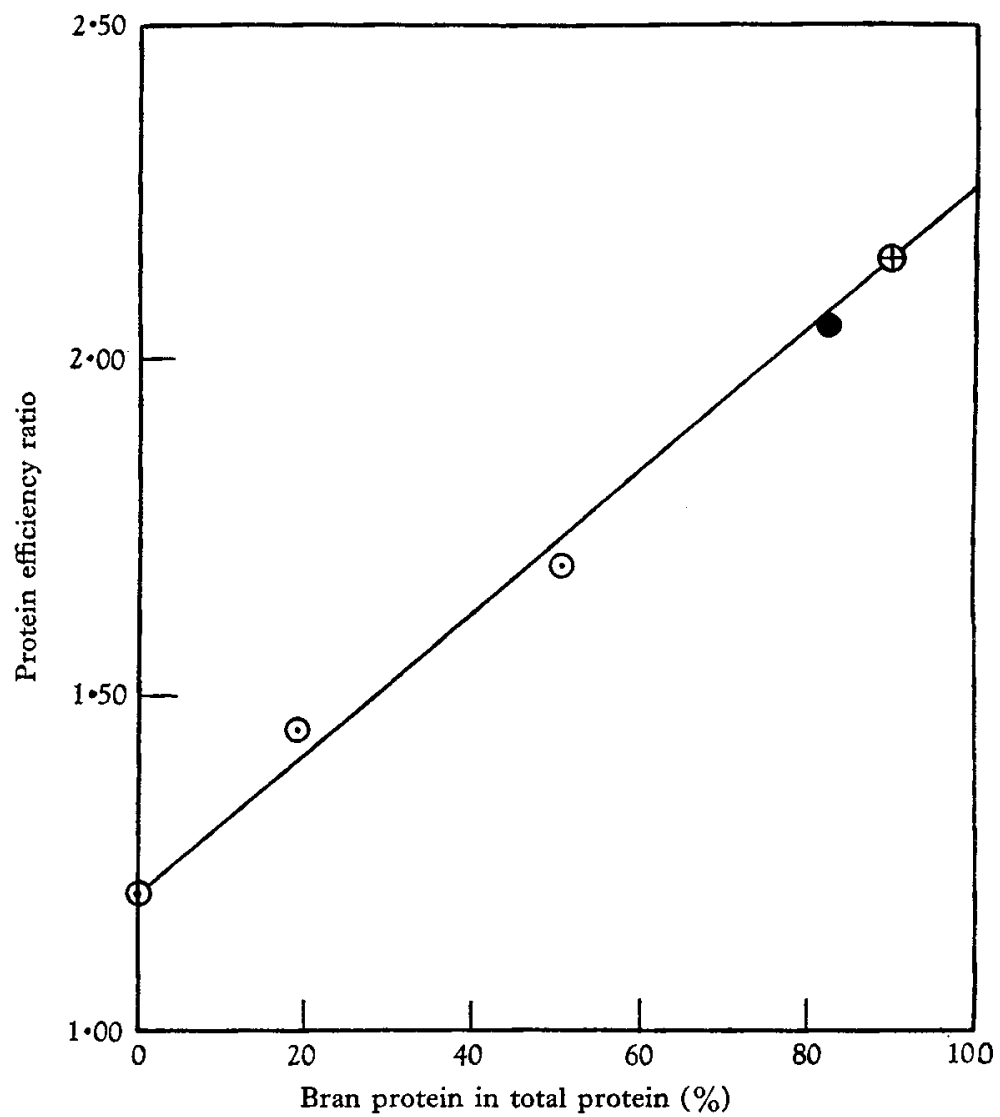

Fig. 2. Relationship between the P.E.R. of the mixed proteins in the diets and the percentage of the total proteins provided by bran.
○ from Exps. 1, 2 and 3.
- from Osborne \& Mendel (1919).
$\oplus$ from Hove et al. (1945).

From this straight-line relationship there is no doubt that the nutritive advantage of adding bran to white flour is due to the addition thus made of some essential nutrient. The nature of this essential constituent is not far to seek, endosperm proteins being poor in lysine and tryptophan, especially the former, and bran proteins containing about twice as much of these essential amino-acids as endosperm proteins (see Jones \& Gersdorff, 1925; Barton-Wright \& Moran, 1946). If, instead of the percentages of bran protein, the percentages of lysine in the mixtures (calculated 
from the figures of Barton-Wright $\&$ Moran) be plotted as abscissae, a straight line also results; in this case the equation of the line is $y=0.47 x+0.27$.

This straight-line function indicates that there is no significant reciprocity on the part of the endosperm proteins, although this might be possible as they contain more leucine and phenylalanine. For, if it were so, the effect of mixing bran proteins with those of white flour would be to produce at first a rise and then a fall in the value of the P.E.R. as the proportion of the former was increased.

\section{The nutritive value of the proteins in the outer layers of the endosperm}

It has been shown by Cobb (1905) that the nitrogen content of the endosperm increases from the centre towards the periphery of the wheat kernel. This has been confirmed by Morris, Alexander \& Pascoe (1945), by Moran (1945) and by Moran \& Drummond (1945). Barton-Wright \& Moran (1946) estimated the amounts of the ten essential amino-acids in the proteins of the outer endosperm and compared them with those of the inner endosperm. Their results suggested that the former were of better nutritive quality. It was, therefore, thought of interest to include in the present series of experiments a further one in which all the nitrogen in the diet was derived from outer endosperm. The sample, provided by Dr Moran, was not obtained from the same grist as the white flour and bran used in Exps. 1-4, but from a grist composed of a similar mixture of wheats. It was prepared by a process in which coarse bran was freed as far as possible from adherent endosperm by successive passage between fluted rollers and finally through a bran finisher in which beaters removed a further quantity of endosperm. In these operations the endosperm separated during the last passage would contain a higher proportion of the outer portions and probably some aleurone. A diet was made similar in composition to diets 97 and 98 (see Table 6) with a sample of this outer endosperm, which contained $2.65 \%$ nitrogen on the dry weight. The nutritive value of its protein, while superior to that of those contained in white flour, was found to be inferior to that of the proteins in the mixtures of white flour and bran in Exps. 2 and 3 (see Table 7 and Fig. I).

\section{SUMMARY}

I. The amount of the aleurone and pericarp was estimated from measurements of the volume of the wheat grain and of the thickness of these two coats. From these measurements it was concluded that the aleurone occupies from 7.5 to $9 \%$ of the volume of the grain, according to the variety of the wheat, and the pericarp somewhat more. This average figure for the aleurone is somewhat lower than that which Girard ( 1884 ) arrived at after separating the aleurone by dissection and weighing it, but corresponds to that recently found by Hinton (Booth \& Moran, 1946).

2. Experiments are described in which bran was treated successively with hot water, saliva, pepsin- $\mathrm{HCl}$ and trypsin at $\mathrm{pH} 8$, and determinations made of the amount of material and of nitrogen dissolved by each treatment. Reckoned in roo g. bran, the average amount dissolved by hot water followed by saliva was $3 \circ \mathrm{g}$., by pepsin 
$9 \cdot 3 \mathrm{~g}$. and by trypsin $4.8 \mathrm{~g}$., making a total of $44.1 \%$. For roo parts of nitrogen in the original bran, the corresponding figures were $26.1,28.6$ and $19 \cdot 2$, making a total of $74 \%$. The gradual disintegration of the aleurone and the disappearance of its cells by in vitro digestion with pepsin and with trypsin is described. The pericarp appeared to undergo little change. From these microscopical observations and from the consideration that, according to Girard, four-fifths of the nitrogen of the bran is contained in the aleurone, it is concluded that the greater part of the nitrogen which was removed by successive treatment with hot water, pepsin and trypsin was derived from the cells of the aleurone.

3. Examination of the contents of different portions of the alimentary tract after feeding bran showed that, in the pig and in some instances in the rat, the action on the aleurone cells had begun in the stomach, was continued in the small intestine and more or less completed in the caecum and large intestine.

4. Determination of the nitrogen in the faeces of rats, fed on a diet containing bran as sole source of nitrogen, showed that, even when three-quarters of the diet was made up of bran, more than $60 \%$ of its nitrogen had been digested and absorbed. As the faecal nitrogen included that derived from intestinal secretions and bacteria, the true figure would be higher.

5. The nutritive value of the nitrogenous substances in bran was tested by their capacity to support growth of newly weaned rats on diets in which a sample of bran containing about II \% of adherent endosperm was the sole source of nitrogen and also when it was mixed with white flour (70\% extraction) in different proportions. The percentage of nitrogen in the diets was suboptimal and was the factor limiting growth; it varied from $\mathrm{I} \cdot 8$ to $2.0 \%$ on dry weight.

6 . When four-fifths of the protein in the diet was derived from white flour and onefifth from bran (Exp. 2), the nutritive value of the mixture was greater than that of the proteins derived wholly from white flour (Exp. I); the average increase in body-weight was $50 \%$ greater and the protein efficiency ratio greater by $20 \%$, notwithstanding a $7 \%$ diminution in the apparent digestibility of the nitrogen in the diet containing the bran. The P.E.R. of the mixtures of proteins in Exps. I and 2 were, respectively, $\mathrm{I} \cdot 2 \mathrm{I}$ and $\mathrm{I} \cdot 44$ and the digestibility coefficients 89 and 83 .

When the proportion of bran was increased to supply about one-half of the nitrogen in the diet there was a further nutritive advantage, the P.E.R. being I.68 (Exp. 3); in this case the coefficient of digestibility of the nitrogen in the diet was lowered to 75 .

7. When the protein was supplied entirely by bran (Exp. 4), the utilization of the nitrogen was inferior to that shown on the diets containing the mixtures with white flour. The coefficient of digestibility of the bran nitrogen was found to be only $63.1 \%$ For this and other reasons which are discussed, it is considered that the value of $x \cdot 34$ obtained for the P.E.R. of bran proteins is an underestimate and that a figure of about 2.0, as found by Osborne \& Mendel (1919), Murphy \& Jones (1926) and Hove et al. (1945), is more correct.

8. The increase in P.E.R. observed on admixture of bran proteins with white-flour proteins was found to be proportional to the percentage of bran proteins in the 
mixtures (see Fig. 2). From this relationship the value of the P.E.R. for the proteins as they exist in bran was estimated to be about $\mathbf{2 \cdot 2 5}$.

9. Since the proteins of bran have been shown by others to contain about twice as much lysine and tryptophan as the corresponding proteins of white flour, the increase in nutritive value of the protein mixtures obtained when increasing amounts of bran are added to white flour can be explained by the additions thereby made of these essential amino-acids.

Io. There may be many reasons for the removal of the bran from the cereals of our diets and others for its retention. In times of peace and plenty a drop in the nutritive efficiency of the proteins left in the white flour is negligible if the diet contains enough eggs, milk and meat. These are, however, scarce at present and, if wheat has to furnish the bulk of the protein as well as of the energy requirements, a loss of 10-12\% in protein efficiency may be of moment.

We desire to thank the Cereals' Research Station, St Albans, and particularly Dr T. Moran, for help in supplying materials suitable for our work; also Mr G. Childs for the bomb calorimetry estimations in Exps. 3 and 4 and Mr G. W. Flynn for help in the care of the experimental animals. The work was carried out at Roebuck House, Chesterton, Cambridge, to which the Division of Nutrition of the Lister Institute was evacuated during the war years, at the invitation of Sir Charles Martin.

\section{REFERENCES}

Barton-Wright, E. C. \& Moran, T. (1946). Analyst, 7x, 278.

Block, R. J. \& Mitchell, H. H. (1946). Nutr. Abstr. Rev. 16, 249.

Booth, R. G., Carter, R. H., Jones, C. R. \& Moran, T. (194I). Chem. Eீ Ind. 60, 903.

Booth, R. G. \& Moran, T. (1946). Lancet, 251, I19.

Borgström, S. (1941). Acta physiol. scand. 2, suppl. vir.

Chick, H. (1942). Lancet, 242, 405.

Chick, H., Copping, A. M. \& Slack, E. B. (1946). Lancet, 250, I96.

Cobb, N. A. (I905). Misc. Publ. Dep. Agric. N.S.W. no. 539.

Eckstein, E. \& Vogel, E. (1942). Ernährung, 7, 33.

Girard, A. (1884). Ann. Chim. (Phys.), ser. vi, 3, 289.

Guillemet, R. \& Jacquot, R. (I944). Bull. Soc. Chim. biol., Paris, 26, 324.

Hindhede, M. (1923). F. Amer. med. Ass. 8o, 1685 .

Hove, E. L., Carpenter, L. E. \& Harrel, C. G. (1945). Cereal Chem. 22, 287.

Jacquot, R., Trémolières, J., Guillemet, R. \& Erfman, R. (1944). Bull. Acad. Med. Paris, nos. 31-2, p. 608 .

Johansson, H. (1917). Svenska LäkSällsk. Förh. p. 302.

Jones, D. B. \& Gersdorff, C. E. F. (1923). F. biol. Chem. 58, i 17.

Jones, D. B. \& Gersdorff, C. E. F. (1925). F. biol. Chem. 64, 24 I.

Klein, A., Harrow, B., Pine, L. \& Funk, C. (1926). Amer. $\mathscr{F}$. Physiol. 76, 237.

McCollum, E. V., Simmonds, N. \& Pitz, W. (r917). F. biol. Chem. 29, 521.

Macrae, T. F., Hutchinson, J. C. D., Irwin, J. O., Bacon, J. S. D. \& McDougall, E. L. (1942). F. Hyg., Camb., 42, 423.

Marais, J. S. C. \& Smuts, D. B. (1940). Onderstepoort F. vet. Sci. 15, 205.

Mitchell, H. H. (1924a). F. biol. Chem. 58, 873.

Mitchell, H. H. (1924b). $\mathcal{F}$. biol. Chem. 58, 905 .

Mitchell, H. H. \& Carman, G. G. (1924). F. biol. Chem. 60, 613.

Moran, T. (1945). Nature, Land., 155, 205.

Moran, T. \& Drummond, J. C. (1945). Lancet, 248, 698.

Morris, V. H., Alexander, T. L. \& Pascoe, E. D. (1945). Cereal Chem. 22, 35 I. 
Murphy, J. C. \& Jones, D. B. (1926). 7. biol. Chem. 59, 85.

Osborne, T. B. \& Mendel, L. B. (1919). F. biol. Chem. 37, 557.

Osborne, T. B., Mendel, L. B. \& Ferry, E. L. (19г9). F. biol. Chem. 37, 223.

Rubner, M. (1883). Z. Biol. r9, 45.

Stokes, J. L., Gunness, M., Dwyer, I. M. \& Caswell, M. C. (1945). F. biol. Chem. 60, 35.

Wiegner, G. (1918). Mitt. Lebensm. Hyg., Bern, 9, 289.

Winton, A. L. \& Winton, K. B. (1932). Structure and Composition of Foods. New York: John Wiley and Sons Inc.; London: Chapman and Hall Ltd.

\section{Levels of Serum Alkaline Phosphatase among Infants (2-27 months) in the British Zone of Germany*}

By MARGARET I. STERN, No. 2 Nutrition Survey Team, Celle, B.A.O.R.

(Received 4 fuly 1947)

The occurrence of rickets in the British Zone of Germany has increased since the end of the last World War, and it was thought useful to carry out an investigation of the serum alkaline phosphatase levels among infants. The ages of the children of whom the following figures are published varied from 2 to 27 months, and all, except one, were living in institutions at the time of the investigation, viz. fifty-two in the Kinderhospital, Celle; forty-four in an U.N.R.R.A. nursery at Auemuehle, near Celle, and eight in a Celle nursery for orphans.

\section{EXPERIMENTAL}

Procedure. Blood was drawn by a German physician from either the anterior fontanelle, or the jugular vein. About $5 \mathrm{ml}$. were collected and allowed to clot. The samples were stored overnight in a refrigerator. In a number of cases, blood was taken from the same infants after intervals of several months. Here, in each case, only one (random) determination has been included.

It must be pointed out that the sampling, although random in the group, will be weighted in favour of 'ill' babies, as $50 \%$ were patients in the Kinderhospital. As far as could be ascertained, none of the infants suffered from any disease, except bone diseases, likely to give high values of serum alkaline phosphatase. Klasmer (1944) found discoloration of serum in some infants, suggesting transient hepatic damage, which might be expected in distrophic rather than in healthy children. We found many cloudy serums which did not appear to be due to fat. The remainder, i.e. the 'well' babies, were largely the children of displaced persons.

Measurement of alkaline phosphatase. The method adopted was that of King (1946), with slight modifications for reading the blue colour in a Coleman colorimeter. Disodium phenyl phosphate was hydrolysed under controlled conditions, and the

* This investigation was carried out between September 1946 and May I947. 